\title{
THEORETICAL DEBATES WITHIN CONTEMPORARY RUSSIAN FEMINISM
}

Key words: Russian politics, political ideologies, feminism.

Feminism emerged as an important ideological trend in contemporary Russia. Different strands of this thought focus on divergent problems experienced by Russian women. Some researchers consider the experience of women representing Russia's growing middle class. Others tend to focus on the problems of dispossessed and less privileged layers of the Russian society. The difference in the focus of attention is reminiscent of the pre-existing Western division of the feminist thought on the feminism of equality and feminism of difference. This paper will consider the main directions of these debates in Russia focusing on key aspects pondered by feminism in general. It will also argue that the state deploys both strands of feminist thought selectively in situations that suits its ideological and political purposes.

\section{INTRODUCTION}

Feminism has become an essential part of the ideological landscape of any modern state. This paper examines main theoretical trends within this ideology in contemporary Russia. This account adopts a theoretical framework established in the West at the time of the inception of active debates on the subject. It splits the idea of struggle for women's rights into two broad categories. One claims total equality between men and women. Another strives to accommodate differences between the two sexes and account for the ways in which women may be disadvantaged in contemporary society due to their differences from men. Even though Western critique has developed significantly to include broad variations of feminist trends, many Russian conservative observers, such as Vitaly Tretyakov, Vladimir Soloveov, Sergey Kurginyan, Alexander Dugin, who look at the development of the problem in contemporary Russia from outside the gender studies cohort, hold to this traditional Western methodology. They insist that contemporary Russian feminism should be studied from this particular point of view. This approach is therefore important in that it represents an examination of Russian feminism through the lenses of Russia's conservative discourse. 
Hence, this discussion will show that contemporary Russian feminism could be divided along the two theoretical lines practiced in the West. It will examine debates between these two branches of Russian feminism within the most topical themes. The paper is in four parts. The first part introduces a brief history of feminist ideology and its ensuing conceptual split. The second part examines the idiosyncrasies of Soviet feminism and its impact on the emergence of equality feminism in post-Soviet Russia. The third section considers themes and problems raised by both types of feminism in reference to the Russian case.

\section{THEORETICAL REMARKS: TWO CONCEPTS OF FEMINISM}

Feminism is concerned with the issue of male domination of aspects of socio-political and economic life. From the period of antiquity through to the inception of Christianity, medieval time and modernity the patriarchal mode of social relationship favoured men and their needs. ${ }^{1}$ The onset of modernity with its emphasis on socio-political rights and equality of opportunity failed to change this state of affairs. Foucault argues that modernity deepened the patriarchal component of Western society. ${ }^{2}$ Indeed, through philosophy, art and literature, modernity established a new image of secular masculinity as a social norm and a cardinal behavioural pattern. Affirmation of the male sex helped to advance the idea of liberating humans from God, which broadly fell in line with the Enlightenment goals. Subsequent political and philosophical secularisations of

\footnotetext{
${ }^{1}$ Coole, Diana (1993) Women in Political Theory. From Ancient Misogyny to Contemporary Feminism (London: Harvester Whatsheaf); Pateman, Carole (1989) The Disorder of Women: Democracy, Feminism, and Political Theory (Cambridge: Polity Press); Pateman, Carole (1988) The Sexual Contract (Cambridge: Polity Press); Squires, Judith (1999) Gender in Political Theory (Cambridge: Polity Press).

${ }^{2}$ Foucault, M. (1990) The Will to Knowledge. The History of Sexuality. 1 (London: Penguin Books).
} 
life, which culminated with the Nietzschean 'death of God' thesis, led to a situation in which a secular Man emerged as the main subject of politics.

Hence, modernity built economic, political, and social relationships on masculine terms. It exalted aggression, egoism, and competitive ethos, defined by the newly established and rapidly developing capitalism. Private property, acquisitions, hostile takeovers, nationalism, war, economic and political expansion, stock market speculations - all represented masculine features. Politicians and philosophers of that period had men in mind as beneficiaries from the new world structure and the parameters of the new social contact. ${ }^{3}$

In line with this, however, the logic of modernity enabled women to begin struggling for their rights. The initial struggle took two essentially different but nevertheless complimentary paths. The first option assumed fighting for equal rights with men in the world designed by men. These theorists, whom the literature occasionally refers to as liberals, 'integrationists', 'assimilationists', and 'feminists of equality' ${ }^{4}$, are 'concerned with the ways in which politics has structured gender relations'. ${ }^{5}$ They search for ways to include women within the extant structure of power relations. Such theorists propose to adopt a genderblind androgynous society, in which biological differences have no relevance in the course of social, political, and economic affairs. They represent a liberal trend of thought, considering people primarily as individuals and only then as representatives of particular gender, ethnic, or religious groups.

\footnotetext{
${ }^{3}$ Elshtain, Jean (1992) Meditations in Modern Political Thought: Masculine/Feminine Themes from Luther to Arendt (University Park: Pennsylvania State University Press), p. 7; Foucault 1990.

${ }^{4}$ Freedman, Jane (2001) Feminism (Buckingham: Open University Press), pp. 9-10; Elshtain 1992, p. 2.

${ }^{5}$ Squires 1999, p. 17.
} 
Complementary to them are feminists of difference ${ }^{6}$ or 'transformation theorists' ${ }^{7}$, often referred to as 'rejectionists' ${ }^{8}$ They claim that there are cases in which differential treatment of the sexes is legitimate and even desirable. They begin with sports, job placements, and separate washrooms and end up with proposals to redefine the entire spectrum of social relationships to include and integrate women's perspectives and problems. Their project requires reconstructing the entire ontology of social science to include gender as one of its concepts and to conduct an epistemic shift in the study of power relations. Such thinkers insist that justice and equality could not be achieved if men are allowed to build social institutions in accordance with their standards and expect women to compete in an environment, which they had not originally created. ${ }^{9}$

Hence, the debate between the feminism of difference and the feminism of equality became salient in the political literature of the early stages of development of feminist thought. Subsequently, different and more nuanced trends of feminism appeared. These included postcolonial, Marxist, queer, poststructuralist and other trends. For the purpose of this account, however, I will focus on the two oldest and more prominent debates between the feminism of equality and the feminism of difference for the reasons that I will outline a few paragraphs later. There are areas, in which the feminism of equality and feminism of difference contest. Let us consider those debates that are relevant to

\footnotetext{
${ }^{6}$ Frazer, Elizabeth and Lacey, Nicola (1993) The Politics of Community: a Feminist Critique of the Liberal-Communitarian Debate. (New York: Harvester Wheatsheaf), p. 214; Freedman 2001, p. 9; Kymlicka, Will (2002) Contemporary Political Philosophy (Oxford: Oxford University Press) p. 378-9; Frazer and Lacey 1993, p. 214

${ }^{7}$ Squires 1999, p. 17.

${ }^{8}$ Elshtain 1992, p. 3.

${ }^{9}$ MacKinnon, Sophie (1987) Feminism Unmodified: Discourses on Life and Law (Harvard University Press: Cambridge, Mass.), p. 36; Kymlicka 2002, p. 379; Frazer and Lacey 1993, p. 214.
} 
the subsequent discussion on Russia. These are: (1) the division between public and private, (2) labour relations, (3) conceptions of power, and (4) models of citizenship.

First, the separation between the public and private spheres is a central element of the liberal ideology. Despite this, however, the two branches of feminism do not find consensus on this issue. Feminists of difference claim that the division between public and private must be broken. The 'personal is political' slogan represents the locus of their critique. They reject the traditional idea that the political is located strictly within the sphere of institutions and government. Rather they claim that politics are ubiquitous and all encompassing. ${ }^{10}$ They argue that exploitation via unpaid domestic work, abuse, and neglect of women have taken place in the private sphere since the period of antiquity. From this point of view, the private sphere represents a matter of political attention. ${ }^{11}$ Liberal feminists, in contrast, are reluctant to part with the public-private distinction. This type of feminism merely seeks to open the public sphere to equal participation for men and women. ${ }^{12}$ These theorists suggest that if women stay in the sphere of domestic life, it is their personal choice and even their natural predisposition. This thought attracts women who have a higher educational and social status that could allow political participation on equal terms with men.

Second, labour policy is the area in which the two strands of feminism differ. Feminists of difference argue that many job descriptions have been

\footnotetext{
10 Di Stefano, Christine (1996) 'Autonomy in the Light of Difference' in Nancy Hirshchman and Christine Di Stefano (eds) Rethinking Obligation (Ithaca, N.Y.: Cornell University Press), pp. 95116; Squires 1999, p. 23.

11 Kymlicka 2002, p. 381.

12 Friedan, Betty (1963) The Feminine Mystique (New York: W. W. Norton and Co.).
} 
drafted to fit a male image. Gender inequalities, they argue, are built into the very definition of various employed positions in the spheres of blue-collar work, the military, education, public politics, and academic work. ${ }^{13}$ Liberal feminists, on the other hand, are reluctant to accept the argument that job descriptions must be specified in the fashion that could take difference between men and women into account and create conditions that would adapt to women's specific needs. Instead, they take pride in women's capabilities to take part in male-dominated jobs and prefer to ignore any existing physical differences.

The definition of power is the third area, in which the two strands of feminism enter into a mutually enriching dialogue. Liberal feminists tend to support the so-called male definition of power and argue that women are good at deploying this model in business and politics. This definition, initially proposed by Stephen Lukes, is based on the idea of conflict. In this model $A$, using various methods from direct imposition to persuasion, 'can get $B$ do something that $B$ would not otherwise do'.14 The feminist conception of power, in contrast, assumes that $A$ and $B$ seek consensus and want to co-operate. Hannah Arendt gives the best description of this power model. She writes: power 'corresponds to the human ability not just to act but to act in concert. Power is never the property of an individual; it belongs to a group and remains in existence only so long as the group keeps together. When we say of somebody that he is 'in power' we actually refer to his being empowered by a certain number of people to act in

\footnotetext{
${ }^{13}$ Radcliffe-Richards, Janet (1980) The Sceptical Feminist: A Philosophical Enquiry (London: Routledge and Kegan Paul), p. 112-14; MacKinnon 1987, p. 37; Kymlicka 2002, p. 379.

${ }^{14}$ Lukes, S. (1978) Power: A Radical View. (London: Macmillan), pp. 11-2.
} 
their name'.15 This model of power mainly refers to informal ways of influence and excludes zero-sum games. ${ }^{16}$

Finally, in the sphere of citizenship theorisations, two clearly defined categories can be distinguished. In the first case, citizenship assumes a genderblind attitude to all members of society and advocates the idea that both men and women should have equal access and take equal part in the public sphere. ${ }^{17}$ The second approach claims that the contribution of women and their difference from men must be taken into account. Such theorists claim that the ideal of gender-neutral citizenship is unattainable and that women, in order to receive full citizenship, will have to adapt to the citizenship template fashioned and defined in a male image. ${ }^{18}$ This idea of citizenship emphasises the concept of the public good, in which duties of each citizen are viewed as a source of sustaining good public life and order. ${ }^{19}$

The theoretical framework that divides feminism on the two complimentary branches of difference and equality becomes important from the point of view of Russian conservatives and critics of feminism. Conservatives usually view Russian feminism in this dichotomous fashion and harbour hopes in deploying feminism to their advantage in situational cases. ${ }^{20}$ Because Russia's

\footnotetext{
${ }^{15}$ Arendt, Hannah (1969) On Violence (New York: Harcourt, Brace and World), p. 44.

${ }^{16}$ Squires 1999, p. 40; Elshtain 1992, p. 116.

${ }^{17}$ Heater, D. (1990) Citizenship: The Civic Ideal in World History, Politics, and Education (London: Longman).

${ }^{18}$ Lister, R. (2003) Citizenship: Feminist Perspectives (MacMillan: Basingstoke), pp. 94-6; Vogel, U. (1991) 'Is Citizenship Gender-Specific?', in U. Vogel and M. Moran (eds) (1991) The Frontiers of Citizenship (MacMillan: Basingstoke).

${ }^{19}$ Etzioni, A. (1993) The Spirit of Community: Rights, Responsibilities, and the Communitarian Agenda (London: Fontana); Heater 1990; Pateman 1989, pp. 196-7.

${ }^{20}$ See Alexander Dugin's rhetoric on appealing to Russia's gay community with the view to co-opt them to the promotion of patriotic values program. His deployment of the Tatu group anti-Iraq
} 
ideological scene has taken a conservative turn recently, this approach becomes instrumental in understanding the problem from outside the feminist studies. It could also explicate the behaviour of the Russian state that seeks at times to coopt the two different strands of feminism into its discourse. It relies of the essentialism of the feminism of difference to exalt the ideas of childbirth and ideological attraction of the Soviet welfare state policies. This helps the state to exonerate the Soviet experience and to contribute to the increase in birth rates. The sate also occasionally sides with the feminism of equality to appeal to the core values of Western late modernity with the view to repudiate some of the West's post-modern practices. The rest of this paper will discuss the division of Russian feminism into two similar branches and applies those conceptual issues within both theoretical camps.

\section{RUSSIAN FEMINISM}

Soviet Patterns of Gender Socialization: Feminism of Equality

Researching the landscape of contemporary Russian feminism one can arrive at an interesting conclusion. Thinkers and activists of the Soviet generation usually espouse feminism of equality and stand on the liberal positions, both theoretically and practically. ${ }^{21}$ Younger generations of women who were brought up under the post-Soviet system usually espouse feminism of difference. The picture is undoubtedly more nuanced and complex with various representatives of the feminist movement adhering to both strands of the debate contextually. Yet, the distinctive duality in the approach to the problem persists.

war protest was indicative. The subsequent deliberations to work united with feminism of difference on part of Vitaly Tretyakov and Alexandr Dugin is also a good example.

${ }^{21}$ Shnyrova, O. 'Neprikosnovennyi Zapas', Novoe Literaturnoe Obozrenie, No. 83, March 2012. 
This has become particularly clear with the construction of the 'power vertical' during the 2000s and intensification of the state-centred nativist rhetoric in the public space. Then the liberal feminism began to head more towards the stateoriented nativist movements, while the feminism of difference adhered to more radically liberal, anti-state campaigns. ${ }^{22}$ The particular system of gender relations that was formed under the Soviet and partially Russian Imperial systems could partly explain this. ${ }^{23}$

Liberal feminism, as we have discussed above, concerns itself with the issues of general equality and fends for women whose socio-economic interests have been already observed. Patterns of gender relations of both the Imperial and Soviet periods generally geared towards gender equality and therefore were conducive to the initial predominance of the liberal version of feminism at the post-Soviet stage. Russia, in its Imperial and Communist interpretations, was the first country in the world that granted women the widest political and economic rights. ${ }^{24}$ Women's rights organisations initially emerged between 1861 and

\footnotetext{
22 Ibid.

${ }^{23}$ Akulova, V. (2013) 'Feminizm v Rossii', in Zhivoi Razgovor, 30 March, available at https://www.youtube.com/watch?v=aOYNHmX9bVk; Arbatova, M. (2013) 'Maria Arbatova o Feminizme', in Sobchak Zhivem, 7 March, available at https://www.youtube.com/watch?v=T3rgud-AkSU, last accessed 7 June 2016; Gessen, M. (1998) 'Litsa Feministskoi Natsionalnosti', Itogi, No. 8(93), available at http://www.az.ru/women/texts/gessr.htm, last accessed 7 June 2016.

${ }^{24}$ Khasbulatova, O. (2001) 'Rossiiskaia Gosudarstvennaia Politika v Otnoshenii Zhenshchin (1990-2000)' in Voronina, O. (ed.) Teoriia i Metodologiia Gendernykh Issledovanii (Moscow: MTsGI-MVShSEN), pp. 185-198; Khasbulatova, O. A. (2004) 'Obzor Sovetskoi Gosudarstvennoi Politiki v Otnoshenii Zhenshchin' in Stepanova, N., Kochkina, E. (eds.) Gendernaya Rekonstruktsiia Politicheskikh System (St. Petersburg: Alteia), pp. 397-407; Akhmedina, F., Shnyrova, O., Shkolnikov, I. (2007) 'Opyt Resheniya "Zhenskogo Voprosa” v Sovetskoe Vremia', in Mezentseva, E., Iukina, I. , Boichenko, I. and Tartakovskaia, I. (eds.) Vvedenie v Teoriiu i Praktiku Gendernykh Otnoshenii (Tashkent: Komitet Zhenshchin Respubliki Uzbekistan), pp. 71-81; Chirikova, A. and Lapina, N. (2011) 'Zhenshchina na Vysshikh Etazhakh Rossiiskoi Regionalnoi Vlasi: Bazovye Tendentsii', Politeks, No. 4, pp. 142-62; Zdravomyslova, O. (2001) Na Puti k Novomu Etapu Ponimaniia. Gendernye Issledovaniia v Rossii: Sostoianie i Perspektivy (Moscow: Gorbachev Fond); Seltser, D. (2003) 'Transformatsiia Zhenskoi Politicheskoi Elity: iz SSSR v RF' in Shcherbinin, P. P. (ed.) Zhenskaia Povsednevnost $v$ Rossii $v$ XVIII-XX vv. Materialy Mezhdunarodnoi Nauchnoi Konferentsii 25 Sentiabria 2003 goda (Tambov: TGU im. Derzhavina), pp. 219-227.
} 
1917.25 Despite that the movement went through its peaks $11860-1870$ and 1905-1907) and downturns (following the 1881 murder of Alexander II), the late Imperial period gave rise to women's political solidarity and helped formulate demands towards state and society. ${ }^{26}$ Women became active in business delivering impressive results in various industries and trade. A number of feminist literature journals emerged. Among those were the Zhenskii Vestnik (Women's Times), Zhenskoe Delo (Women Affairs), and Drug Zhenshchin (Women's Friend). ${ }^{27}$ The February 1917 Revolution granted women the right to vote and run for the office. Russia's Interim Government gave women the right to occupy any state power positions, including ministerial ones. ${ }^{28}$

The subsequent Bolshevik ideology also sided with the cause of female liberation. At its incipient stages, it held radical aspirations to fully recast the extant model of the bourgeois family. This trend chimed well with the general purpose of creating a radically new human anthropology based on the ideas of total equality and communal lifestyle. One of the first bills that the Bolsheviks passed upon their arrival in power was the abolition of church marriage and simplification of the divorce procedure. They also legalised civil partnerships, same-sex marriages, as well as marriages between three or more people, and were the first government in Europe to allow abortion. ${ }^{29}$

\footnotetext{
25 Stites, R. (1984) The Women's Liberation Movement in Russia: Feminism, Nihilism and Bolshevism, 1860-1930, (Princeton: Princeton University Press); Shnyrova 2012.

${ }^{26}$ Stites, R. 1984.

27 Chirikova, A. (1998) Zhenshchina vo Glave Firmy (Moscow: Institut Sotsiologii RAN), p. 7.

28 Khasbulatova 2004, p. 343; Chirikova and Lapina 2011, p. 8.

29 'Bolshevistskii Opyt Yuvenalnoi Yustitsii', Russia.ru, 28 February 2013, available at http://www.russia.ru/news/society/2013/2/11/7987.html, last accessed 10 May 2015.
} 
The initial radicalism of the Great October Socialist Revolution rhetoric gave way to the conservative restoration during the 1930s onwards. Traditional family, i.e. that which comprised of one man, one woman, and a number of children, had become an essential 'unit of society' without which building a meaningful Socialist system seemed impossible. At the same time, the idea of gender equality has not left the ideological scene. Men and women were expected to take equal paths in life. They received equal education, applied for jobs equally with both expected to work and equally contribute their respective financial shares to the family budget. The state also inadvertently favoured women in the ideological, educational, and social spheres. In many ways, the post-Stalinist Soviet state purposefully neglected matters of masculinity and explicitly emphasised women's problems. ${ }^{30}$ In line with the new family-friendly policy, the Soviet system sided with 'mother and child' to socially protect them from potential life adversities. This strategy ideologically killed two birds with one stone. On the one hand, it maintained the initial Marxian-Bolshevik line of liberating women from the shackles of a patriarchal family and gave them some sort of start in the socio-economic hierarchy. On the other hand, the policy sustained the new conservative idea of protecting families by encouraging birth and motherhood.

State alignment with women was clearly visible in the sphere of education, where girls were taught an active and self-sufficient approach to life. Most educational, nursing and caring personnel were female, who gave girls

\footnotetext{
${ }^{30}$ Ashwin, S. (2000) 'Gender, State and Society in Soviet and Post-Soviet Russia' in S. Ashwin (ed.) Gender, State and Society in Soviet and Post-Soviet Russia (London: Routledge), pp. 71-89; Foxall, Andrew (2012) 'Photographing Vladimir Putin: Masculinity, Nationalism and Visuality in Russian Political Culture', Geopolitics, Vol. 18, pp. 132-156; Kukhterin, S. (2000) 'Fathers and Patriarchs in Communist and Post-Communist Russia' in S. Ashwin (ed.), (2000) Gender, State and Society in Soviet and Post-Soviet Russia (London: Routledge), pp. 71-89.
} 
initial ideas on how to be a professional self-sufficient woman. Boys, on the other hand, found themselves in a different situation. Boys were often told off for playing active and aggressive games. At the same time, they were expected to be different from girls: they could not cry, they could not behave in a girlish manner, and they could not play with dolls. ${ }^{31}$ In this light, girls grew in an emotional environment that had clearly defined socialisation patterns, while boys had a serious challenge to recast their behaviour later in life to the yet-to-be-defined principles of masculinity. Moreover, in contrast to capitalism, the Communist economic and ideological system had a significant number of feminine features. It was based on the principles of mutuality, common property, sharing and integration. Returning to our previous discussion on the nature of capitalism and its explicitly masculine qualities, Communism, in its idealistic ideological form, represented the reverse, feminine, paradigm. ${ }^{32}$

This environment resulted in a situation, in which the Soviet generation of women developed overtly active, almost masculine, qualities. Women often engaged in quintessentially male, from the then Western perspective, jobs - such as hammering bolts to railroad lines, driving trams and trolley buses, completing various physical tasks in factories, reconstructing street buildings and indoor premises. Hence, for most women family was not the main but a complementary

\footnotetext{
${ }^{31}$ Aleshina, Yu. E. and Volovich, A. C. (1991) 'Problemy Usvoeniya Rolei Muzhchiny i Zhenshiny', Voprosy Psikhologii, No. 4, pp. 74-82 at p. 75.

32 Aleshina and Volovich (1991, p. 77) argue that patterns of Soviet education were mostly feminine, much in line with the feminine nature of Communism as a political system. Soviet school discipline relied on methods of public encouragement and deterrence. It assessed pupils' behaviour on the basis of their contributions to the common good. It awarded co-operation and help to other members of the collective and punished excessive individualism and selfishness. Hence, feminine qualities, such as bonding with others, consensual behavioural strategies, and expressive attitudes, have been encouraged. See also Bronfenbrenner U. (1964) Soviet methods of character education: Some implications for research. Readings in child behavior and development (New York: University of Illinois Press), pp. 262-71.
} 
form of self-realisation. Women often had equal, even leading, family roles, employment was a must, and equal sharing of a family budget was a norm. To buttress these suggestions, 44 per cent of the 2006 FOM (Foundation for Public Opinion) poll respondents, of the Soviet generation, claimed that they grew up in a family headed by women and only 31 per cent answered that their family was headed by a man. ${ }^{33}$ Fascinatingly, this state of affairs has been well reflected in Soviet cinema, literature, and monumental art. Even a cursory look at these gives viewers some glaring expressions of the Soviet idea of gender equality.

At the same time, a serious antinomy was lodged into this pattern of Soviet gender socialisation. Despite these advances towards the gender-equal environment, the Soviet Union remained a patriarchal society at a deep-seated psychological level. ${ }^{34}$ Soviet employment patterns reflected that patriarchal psychological attitude. Boys were favoured at university placements in scientific and technical fields. ${ }^{35}$ In the higher echelons of power, the nomenklatura rules demanded that candidates had specific qualifications and experience, which, though equally applied to both men and women, still unofficially required that women were hired to departments concerned with the social, cultural, and educational spheres. ${ }^{36}$ Therefore, during the collapse of the Soviet Union the share of men employed at the highest positions of power at the federal level has

\footnotetext{
${ }^{33}$ Elena Vovk, 'Otnosheniia v Tsifrakh', Nezavisimaia Gazeta, 21 March 2006.

${ }^{34}$ Sperling, Valerie (2006). 'Women's Organisations: Institutionalised Interest Groups or Vulnerable Dissidents?' in Alfred Evans, Laura Henry, and Lisa Sundstrom (eds.), Russian Civil Society. A Critical Assessment. New York: Sharpe Inc., 161-78, at p. 170; Shnyrova 2012.

35 This was partly the reason why women performed a lot of physical and unintellectual tasks. The Soviet educational system was heavily focused on technical fields on order to match the West in the arms race. Humanities were much less prominent and even suppressed. Less choice and fewer university placements were available and women mostly populated these fields. Those who could not get those humanities placements ended up in manual jobs.

${ }^{36}$ Chirikova and Lapina 2011, 'Zhenshchina na Vysshikh Etazhakh'; Aleshina and Volovich 1991, p. 80 .
} 
been 94 per cent. 85 per cent of men occupied executive positions within the same bodies of power, and 68 per cent of men were employed at positions that assumed important decision-making responsibilities. ${ }^{37}$ By the same token, lower positions of power, such as support staff, consultants, and heads of various departments, have comprised of 50 per cent women. In this case, we were able to detect professional gender segregation.

At the ideological-theoretical level, the state ignored the problem of women's personal development. ${ }^{38}$ The idea of women as self-sufficient subjects of history was lost in the ideological confusion. Notions of collective struggle of women for the cause of the liberation of the proletariat class have been predominant. Liberated women were supposed to work for the benefit of the Soviet people's economy on an equal footing with men. ${ }^{39}$ In this light, Khasbulatova writes: 'resolution of the 'women's question' in the Soviet Union has always had two levels: declared goals, i.e. ideological aspirations, and realisation practice. This is because aspirations to create the conditions for female self-realisation have always been accompanied by pragmatic applications of this challenge to the current tasks of the party and the state'. ${ }^{40}$ Hence, the Soviet state appropriated the women's question to serve its needs and ideological goals. En route, it intuitively followed the liberal feminist pattern that declared gender blind equality between men and women. In practice, however, such equality and struggle for women's right served the expediency of the

\footnotetext{
37 Chirikova and Lapina 2011, 'Zhenshchina na Vysshikh Etazhakh'.

38 Voronina, O. (2004) Feminizm i Gendernoe Ravensto (Moscow: Editorial URSS), pp. 132-3.

${ }^{39}$ Aivazova, S. (1998) Russkie Zhenshchiny v Labirinte Ravnopraviya (Moscow: RIK Rusanova); Voronina 2004, pp. 132-3.

40 Khasbulatova 2004, p. 398 and p. 401.
} 
political moment and in the end of the day propelled men to the dominant institutional positions.

\section{FEMINISM IN RUSSIA: EQUALITY AND DIFFERENCE}

The fall of the Soviet Union, along with the ensuing liberalisation of the ideological environment and labour market, created more opportunities, as well as personal and professional aspirations for women. Hence, pressures towards changing the extant pattern of gender relations in favour of greater recognition gradually surfaced. Due to the reasons outlined above, women of Soviet generations were more open to the ideas of feminism of equality rather than to the ideas of feminism of difference. Writers working within the feminism of equality strand are inclined to think that, in Russian society, typically male or typically female behavioural models are very rare and mixed androgynous behaviour is more common. ${ }^{41}$ Therefore, they propose to study masculine and feminine behaviour as complementary. ${ }^{42}$ These writers mainly focus on

\footnotetext{
${ }^{41}$ Kon, I. and Temkina, A. (2009) 'Homo Sexualis I Sovremennost: Zakonchilas li Seksualnaia Revolutsia?' in Gender Dlia Chainikov (Moscow: Heinrich Bulle Foundation), pp. 89-113; Kon, I. and Iusupova, O. 'Materinstvo I Otsovstvo: Sotsiologicheskii Ocherk' in Gender Dlia Chainikov (Moscow: Heinrich Bulle Foundation), pp. 113-37.

42 Temkina, A., Zdravomyslova, E. and Rotkirkh, A. (2009) Sozdanie Privatnosti kak Sfery Zaboty, Luibvi I Naemnogo Truda. Novyi Byt v Sovremennoi Rossii: Gendernye Isseldovaniya Povsednevnosti (European University of St Petersburg: St Petersburg), pp. 7-30; Nikulina, T. and Kharlamenkova I. (1998) 'Polovozrastnye Razlichiya v Stremlenii Lichnosti k Utverzhdeniyu I Zachshite "Ya"' in Abulkhanova, A. V., Brushlinskii, A. V., Volovikova, M. I. (eds) Rossiiskii Mentalitet: Voporsy Psikhologicheskoi Teorii i Praktiki (Moscow: IP RAN), pp. 224-240; Poznyakov, V. P. (2006) 'Gendernye Osobennosti Sotsialno-psikhologicheskikh Kharakteristik Rossiiskikh Predprinimatelei', Institut Psikhologii RAN, Moscow.University for Humanities, http://www.ipras.ru/cntnt/rus/media/on-layn-bibliote/otdelnie-statis/publikacii/rossijskie4/n4 poznyako.html, last accessed 25 May 2015; Kagan, V. E. (1989) 'Stereotipy Muzhestvennosti I Zhenstvennosti I Obraz "Ya" u Podrostkov', Voprosy Psikhologii, No. 3, pp. 53-62; Chirikova and Lapina 2011; Iusupova and Kon 2009; Aleshina and Volovich 1991.
} 
successful women who achieved higher social status and impressive careers within commercial and political spheres. ${ }^{43}$

Feminism of difference emerged with the evolution of the capitalist economic model in Russia. Gradual withdrawal of the state from the sphere of social welfare left women defenceless in an economic and political system that has been drafted to benefit men economically and politically. The 2000-1 administrative reform liquidated Departments for the Affairs of Children, Women, and Families. The Commission for Women's Affairs, which was usually managed by the vice Prime Minister for Social Development, has also been abolished. Family was gradually becoming the sphere of exploitation for women in lower income and lower education groups. Feminists of difference struggle against political and economic domination and its social consequences. Their main goal is a profound change of social consciousness that sustains the world constructed on the principles of patriarchy. ${ }^{44}$ These feminists research the problems faced by younger, lower income, lower education and socially excluded women. In many ways, feminists of difference purposely eschew case studies of Russia's successful women. They claim that such women embraced capitalist rules of the game constructed by men and that they represent men from the gendered point of view. ${ }^{45}$

\footnotetext{
${ }^{43}$ Chirikova, A. (2011) 'Zhenshina-rukovoditel vo vlasti i biznese: sotsialno-psikhologicheskyi portret', Politex, Vol. 7, No. 1, pp. 142-62; Chirikova, A. and Lapina, N. (2011) Zhenshchina na Vysshikh Etazhakh Vlasti. Rossiiskie Praktiki i Frantsuzskii Opyt (Moscow: Institut Sotsiologii Rossiiskoi Akademii Nauk).

44 Temkina, A. and Zdravomyslova, E. (2009) 'Ushel li V Proshloe Patriarkhat? Spetsificheslaia Vlast Slabogo Pola' in Gender Dlia Chainikov (Moscow: Heinrich Bulle Foundation), pp. 25-43.

45 Anna Narinskaya and Olga Lipovskaya in 'Feminizm v Rossii' available at https://www.youtube.com/watch?v=aOYNHmX9bVk, last accessed 2 May 2016.
} 
Let me examine attitudes of both strands of Russian feminism to conceptual issues of labour relations, power models, and the public and private divide.

\section{Public and Private}

In the spheres of the public and private, Russian feminism of equality and feminism of difference hold divergent views. Feminism of difference calls to blur the borders between the private and political and make private matters the focus of political attention. They tackle the problems of domestic violence, lifestyles, family duties, and abortions. Feminism of equality, on the other hand, supports the principle of non-intervention into the private sphere, which often finds situational and contextual intersection with the position of the Russian state. The very state policy towards this matter is marked by some dualism. Apart from the task of increasing birth rates, the state generally insists that it should not interfere into family matters.

In this the Russian state followed the line of traditional Western modernity which sustained the idea of a traditional family, strict division between public and private, and declared equality between men and women in the public as well as domestic realms albeit on the already established male terms. Russia's President Vladimir Putin supported such rhetoric on many occasions impacting on policy-making. His attitude to the draft law on domestic violence was ambiguous in that he claimed that the state must not intrude in family matters and must 'act carefully'. When problems concerned Western postmodern practices that account for the more developed and sophisticated forms of capitalism, the Russian state retreated and acted against the neo-liberal and 
post-modern pattern. On many other occasions Putin endorsed public gatherings (Congress of Russia's Parents is one such example) that denounced the practice of juvenile justice and recasting of the idea of traditional family in West European countries. This practice, in the view of such conference participants, is aimed at destruction of the traditional family and allowing the state to interfere too deeply into the child-rearing process. ${ }^{46}$

It is clear that liberal feminists in Russia find some situational crisscrossing with the state in its defense of the private sphere and declared gender equality. These researchers often focus on the lifestyle of Russia's emerging middle class. They observe the convergence of this stratum's perceptions with those practiced in the West during the late modernity era. Temkina and Zdravomyslova claim that with the fall of the Soviet Union the family became a realm of private life. ${ }^{47}$ Middle class members ardently guard this sphere from external interference. They chose their circle of friends and admitted individuals carefully. They are conscious not to let the state (and the public) intrude into their private sphere. For many middle class women private sphere has become an arena of self-realization. In some respects, guarding the private realm and viewing it as an area in which each member has a particular private function represents a compensatory dynamic adopted by Russia's emerging middle class with the fall of the Soviet Union.

Liberal feminists also criticize any intrusions into private life, primarily on theoretical grounds. We have already observed that, on a theoretical note, authors working within the feminism of equality tradition advocate a type of

\footnotetext{
46 'Bolshevistskii Opyt Yuvenalnoi Yustitsii, Russia.ru, 26 February 2013'.

${ }^{47}$ Temkina, Zdravomyslova, and Rotrikh 2009, pp. 10-2.
} 
equality between men and women that could transcend biological distinctions that exists between the sexes. Some authors, such as Aivazova, Temkina and Zdravomyslova side with the advances in medical technologies that allow women to postpone motherhood or grant men with the technical capability to give birth. ${ }^{48}$ These medical advances, they argue, allow us to destroy the usual perceptions of gender duality. Therefore, intruding into family matters by overly protecting women would invariably result in recognizing differences between men and women and buttressing the binary vision of sexes. Liberal feminists claim that this position leads to a theoretical fallacy. For it undermines the very idea of equality between men and women - a departing point for the entire theory of feminism and its main political objective. 49

This junction leads them to criticism of contemporary Russian state policies towards increasing birth rates, the promotion of motherhood, and institutional defence of 'working mother'. At this point, liberal authors censure the state for its newly embraced political conservatism, excessive advocacy of the 'mother and child' idea, and patriarchal and state-patriotic rhetoric. ${ }^{50}$ Shisheliakina, analysing political discourse of the 2000s, regrets that the state began to marginalise women to the roles of working professionals and a childrearing service for the state. By doing so, she argues, officials actively intruded

\footnotetext{
${ }^{48}$ Aivazova, S. (2008) Rossiiskie Vybory: Gendernoe Prochtenie (Moscow: Moskovskie Uchebniki i Kartolitographiia); Temkina and Zdravomyslova (2009) (eds.) 'Gendernyo Podkhod v Issledovanii Reproduktivnykh Praktik. Preodolenie Nedoveriya k Reproduktivnoi Meditsine' (European University of St Petersburg Press: St. Petersburg), pp. 7-18.

${ }^{49}$ Voronina 2004, pp. 125-9; Shisheliakina, A. (2015) 'Feminnost v Diskursivnom Prostranstve Rossiiskogo Establishmenta', Zhenshchina v Rossiiskom Obshchestve, Vol. 74, No. 1, pp. $62-70$.

${ }^{50}$ Borisova, N. and Gorshkov, A. (2008) 'Politicheskii Potentsial Muzhskikh i Zhenskikh Soobshchestv v Sovremennoi Rossii', Vestnik Permskogo Universiteta, Vol. 1, pp. 34-47; Lapina, N. (2007) Uroki Sotsial'nykh Reform v Rossii. Regional'nyi Aspekt (Moscow: INION RAN); Chirikova and Lapina 2011 p. 10; Temkina and Zdravomyslova 2009, p. 9; Iusupova and Kon 2009, p. 115; Aivazova 1998; Shisheliakina 2015.
} 
into the private realm, criticising women for their decisions to make abortion or to choose a childfree lifestyle. ${ }^{51}$ Aivazova further insists that giving birth has long become a right and not a duty of women. ${ }^{52}$ Both authors lament the return to the old Soviet patterns of intervention into private family matters.

These thinkers also insist on the gender-blind equality within contemporary families. 53 They claim that each spouse must assume the particular sphere of responsibility in which his/her output is the highest. These responsibilities must be located either in the public or private realms. A person's gender plays no role in the overall campaign for achieving equality within a family. Family members must calculate the costs of living and household work and determine the best professional arrangement for both parties and the family as a whole. This would mean that, if the cost of women's work in the public labour market is lower than that of men, and women's productivity is higher in the household, then it makes more sense for men to work in the public sphere and for women to focus on the private domain.

Finally, liberal activists accuse those who promote a feminism of difference of being in collaboration with radical movements that use profanations and bold challenges to the Russian tradition. ${ }^{54}$ Feminists of equality feel that such behaviour destructs the border between public and private and

\footnotetext{
${ }^{51}$ Shisheliakina 2015.

52 Aivazova 1998.

${ }^{53}$ Maltseva, I. and Roshchin S. (2006) Gendernaia Segregatsiia i Mobilnost na Rossiiskom Rynke Truda (Moscow: Higher School of Economics) at p. 11; Mezentseva, E. (2003) 'Muzhchiny i Zhenshchiny v Sphere Domashnego Truda: Logika Ekonomicheskoi Ratsionalnosti Protiv Logiki Gendernoi Identichnosti' in Mezentseva, E. (ed.) Gendernoe Ravenstvo: Poiski Resheniia Starykh Problem (Moscow: MOT), pp. 50-71; Kon and Temkina 2009.

54 Pro-Kremlin organisations often deploy similar tactics. Of particular importance were the Rip for Putin (Porvu Za Putina) campaign or the pro-Putin calendar photo session (see Sperling's fascinating 2012 account). Kremlin's promotion of the image of Vladimir Putin also shocks the audience (see Faxall 2012 discussion on the political nature of masculinity in Russia).
} 
hollows out political debates. They call for focus on 'serious' issues of public significance. Maria Arbatova, one of the oldest representative of the egalitarian feminist movement in Russia, claims that Russian feminism 'needs to be rid of clownish manifestations of feminity and masculinity, artist groups that campaign with the use of awe and profanations, actionist collectives, such Pussy Riot and Voina, which, though raising some important socio-political issues, take away the debate from the actual problems of Russian women'. Arbatova further argues that, 'when Russian feminism obtains political seriousness, one could talk meaningfully about problems and challenges that Russian women face in real life'. 55

In contrast to liberal feminists, Russia's feminists of difference are advocates of the 'private is political' idea. These feminists argue that, when the public and private becomes strictly separated, as it is the case in Western liberal and early capitalist societies, women become left to face a bitter choice between family and career. These activists sustain the argument of their Western counterparts, agreeing that in such social settings the family turns into an arena of women's exploitation. Vera Akulova, a leader of the Moscow Feminist Group, claims that, within a patriarchal family, women become dependent on men

55 'Feminizm v Rossii', available at https://www.youtube.com/watch?v=aOYNHmX9bVk, last accessed 2 May 2016. Arbatova's opinion has some truth. The perceived lack of 'seriousness' of radical feminism of difference bears negatively on the Russian public opinion. Various polls showed that the Russian public was extremely cautious of the ideas of radical feminism and often confused the very notion of feminism with its radical branch. Opinion polls conducted by the Integration Agency in 2012 among 8400 respondents support such attitudes. 36 per cent of female respondents did not support ideas of feminism, while 12 per cent spoke categorically against these ideas. Only seven per cent of female respondents considered themselves as feminist, and 45 spoke for some equal rights with men but did not consider themselves feminists (see 'Otnoshenie k Femeniszmu Zhitelei Rossii, Ukrainy i Belarusi', 17 August 2012, available at http://gtmarket.ru/news/2012/08/17/4898). Male respondents returned similar results. Only 3 per cent felt that they supported feminist women. 45 per cent have had very negative feelings about feminists. 14 per cent were generally positive about the ideas of feminism, and 38 per cent were neutral about it. 
financially, which opens opportunities for physical and psychological abuse. Hence, domestic violence becomes the prime object of study for Russia's feminists of difference. ${ }^{56}$ Researchers claim that data from the country's telephone hotlines shows that between 40,000 and 50,000 women are raped, and between 12,000 and 15,000 women die as a result of domestic violence each year. This figure amounts to approximately 40 deaths per day. ${ }^{57}$ Data collected from Russia's Ministry of Interior confirms these figures. ${ }^{58}$ More importantly, older, less educated, and lower income women are among the vast majority of victims. This is significant because these categories of women require state social protection most.

It is indicative that, as of spring 2015, Russia did not have a law on the prevention of domestic violence. The absence of this law meant that no criminal investigation against a violent party could proceed without a victim's official statement. This situation practically keeps perpetrators' hands free. However, given that most victims of domestic violence are women of older age, lower education and income, they are reluctant to call the police or write a statement. ${ }^{59}$ Hence, over 60 per cent of domestic violence incidents go unreported. It is also important that a lot of the female prison population in Russia is composed of women who murdered or physically harmed their violent partners in self-

\footnotetext{
${ }^{56}$ Akulova 2013.

57 Olga Slobodchikova, 'Zhenshchiny v Rossii: Mezhdu Feminizmom i Patriarkhatom' BBC Russian Service 27 October 2014, available at http://www.bbc.co.uk/russian/russia/2014/10/141025 russia sexism violence stereotypes, last accessed 25 March 2015; see also Vera Akulova, 'Feminizm v Rossii', Zhivoi Razgovor, Setevizor, 30 March 2013, available at https://www.youtube.com/watch?v=aOYNHmX9bVk, last accessed 25 March 2015.

58 Ibid.

${ }^{59}$ Bitten, N. (2013) 'Biet Znachit Lyubit. O domashnem Nasilii i Seksizme v Rossii' in Setevizor. Est Takaia Tema s Nikolaem Pivnenko, 30 May, available at https://www.youtube.com/watch?v=5YjJRMHltLE\&spfreload=1, last accessed 7 May 2016.
} 
defence. ${ }^{60}$ The draft law on the prevention of domestic violence was to be considered by the State Duma in the autumn 2015 session. It was hoped that its introduction could deter domestic violence and its adverse social consequences, as well as provide care to victims. ${ }^{61}$ Yet, the law has yet to be adopted.

Feminists of difference argue that the delay in the adoption of this law stems from the state's ideological refusal to interfere into the traditional family realm. ${ }^{62}$ At the same time, the notion of non-interference into the private family sphere has a peculiar double meaning. The state treats families as a single indivisible unit with the view to ensure higher birth rates. This in itself means intruding into private matters and imposing a traditionalist ideology that strictly divides spousal roles. The state and Church in Russia united in this patriarchal approach to the family realm, pedalling these traditionalist values. Both institutions emphasise that it is necessary for women to give birth. To reflect this institutionally, the state restricted women's right to abortion in 2012.

Prior to 2012, women could get national health abortion funding for socalled 'social reasons'. These included cases of lower income, unemployment, and difficult personal circumstances. The 2012 amendments to law No. 5487 'On the Health of Citizens of Russian Federation' (Ob Okhrane Zdorovya Grazhdan

\footnotetext{
60 'Litsa Zony: V Zhenskoi Kolonii Mechtayut o More, Semye, i Fiskashkakh', gazeta.ru, 24 March 2015, available at http://www.gazeta.ru/social/2015/03/23/6611845.shtml, last accessed 25 March 2015.

61 'Gosduma Mozhet Rassmotret Zakon o Profilaktike Domashnego Nasiliya', Rossiiskaya Gazeta, 8 July 2014, available at http://www.rg.ru/2014/07/08/nasilie-site-anons.html, last accessed 25 March 2015; see also 'SPCh Prosit Putina Podderzhat Zakon o Profilaktike Domashnego Nasiliya', RIA Novosti, 29 July 2014, available at http://ria.ru/society/20140729/1018041099.html, last accessed 25 March 2015.

62 Vladimir Putin, in particular, pointed in a conversation with Russia's Human Right Representative Mikhail Fedotov that family legislation must be drafted in a manner that would ensure that the state would not have the right to excessive interference in the private realm of the family. See 'SPCh Prosit Putina Podderzhat Zakon o Profilaktike Domashnego Nasiliya', RIA Novosti, 29 July 2014, available at http://ria.ru/society/20140729/1018041099.html, last accessed 25 March 2015.
} 
Rossiiskoi Federatsii) restricted the range of such reasons to cases in which pregnancy originated in the result of criminal activity (rape). ${ }^{63}$ The law particularly affected women from lower income groups who are often more in need of assistance with abortions. Indeed, women of higher and average income groups could afford an abortion in a private clinic, while their lower income counterparts find themselves in a different situation. The outcome was further instances of domestic violence and an increased mortality rate for lower income women due to unprofessional abortions and self-harm.

At this point, both feminist of difference and feminists of equality converge in their criticism of the Russian state considering it as patriarchal and intrusive. However, in contrast to the feminism of equality, feminists of difference feel nostalgic of Soviet gender policies. They claim that Soviet consistency in pursuing the 'mother and child' line created a more comfortable environment for women. They also support early Communist undertakings aimed at sharing domestic duties equally between spouses and rewarding domestic work. It is important that this early radical ideological outlook irretrievably breaks the separation between the public and private. Some early Soviet ideologues advocated communal living in which childrearing and domestic work would be the task of various social institutions, instead of a private family matter. This was reflected in early Soviet architecture journals

\footnotetext{
63 'Novye Ogranicheniya Prava na Abort v Rossii', Demoskop Weekly, 20 February - 4 March 2012, available at http://demoscope.ru/weekly/2012/0499/reprod02.php, last accessed 25 March 2015.
} 
that drafted designs for Communal Living Houses, as well as in the general Soviet house designs that had very small kitchens. ${ }^{64}$

Leo Trotsky in The Revolution Betrayed was the most ardent advocate of these ideas. He argued that 'the place of the family as a shut-in petty enterprise was to be occupied, according to the plans, by a finished system of social care and accommodation: maternity houses, crèches, kindergartens, schools, social dining rooms, social laundries, first-aid stations, hospitals, sanatoria, athletic organizations, moving-picture theatres, etc. The complete absorption of the housekeeping functions of the family by institutions of the socialist society, uniting all generations in solidarity and mutual aid, was to bring to woman, and thereby to a loving couple, a real liberation from the thousand-year-old fetters' ${ }^{65}$ Russian feminists of difference explicitly support those ideas, which separate them from their liberal counterparts focusing on the issues of middle class women. Bitten argues: 'we must recast social mentality and provide women with workplaces in social outlets such as nursery schools, restaurants, fast food preparation services, laundrettes, and other outlets, which could relieve them from domestic work and bring them out into the public realm. This could make women more independent and help constructing a symmetrical equal family'.66

\footnotetext{
${ }^{64}$ Kuzmin, N. (1928) 'O Rabochem Zhilishchnom Stroitelstve', Sovremennaiaya Arkhitektura, No. 3, pp. 82-3; Kollontai, A. (1923) Polozhenie Zhenshchiny v Evoliutsii Khoziaistva (Moscow: GIz), p. 33. Temkina, A., Zdravomyslova, E. and Rotkrikh, A. 2009, p. 7.

65 Trotsky, L. (2004, first published in 1937) The Revolution Betrayed (Dover Publications: United States of America, Minnesota), pp. 109-10.

${ }^{66}$ Bitten, N. '8 Marta - prazdnik dlia kogo?', Radio Liberty, available at http://www.svoboda.org/audio/26886064.html, 8 March 2015, last accessed 1 May 2016.
} 


\section{Labour Relations}

In the sphere of labour relations, both strands of feminist thought ponder similar issues. Yet they raise different points of importance. First, feminists of equality usually focus on women's participation in business and power institutions. ${ }^{67}$ They optimistically claim that women are gradually occupying important positions of power within Russia's financial, political, and business spheres. Feminists from the 'difference camp', in contrast, usually focus on women of lower income groups. They tackle the issues of professional, social, and economic discrimination of women and problems associated with pay gaps for male and female labour. Second, both strands of feminism examine issues of professional gender segregation. In the feminism of equality case, thinkers claim that such segregation does not always represent the result of deliberate discrimination of women. Feminism of difference, on the other hand, claims that professional gender segregation takes place as a result of the masculine domination of the entire structure of social relationships. Let me discuss these matters in detail.

First, feminists of equality usually point out that, due to a multitude of historic and ideological reasons, ${ }^{68}$ Russia is among leading countries of the West in the sphere of women's employment. In the Soviet Union the share of women in the labour market equalled 77.4 per cent and 88.2 per cent in 1960 and 1980 respectively. These figures looked considerably higher than during the same

\footnotetext{
${ }^{67}$ Zaslavskaya, T. (2006)a 'Avangard Rossiiskogo Delovogo Soobshchestva: Gendernsyi Aspekt. Statia 1', SotIs, No. 4; Zasvalskaya, T. (2006)b 'Avangard Rossiiskogo Delovogo Soobshchestva. Statia 2', SotsIs, Vol. 5; Ogloblin, C. G. (1999) 'The Gender Earnings Differential in the Russian Transition Economy', Industrial and Labour Relations Review, Vol. 52, No. 4, pp. 602-627; Chirikova 2001; Chirikova and Lapina 2011, Maltseva and Roshchin 2006; Mezentseva, E. (2000) 'Gendernaia Ekonomika: Teoreticheskie Podkhody', Voprosy Ekonomiki, No. 3, pp. 54-65.
}

68 Ogloblin 1999. 
years in the United States with 37.8 and 51.3 respectively, France with 44.5 and 57.0 per cent respectively, Germany with 46.5 and 56.2 per cent respectively and Britain with 43.4 and 62.3 per cent respectively. ${ }^{69}$ In 1985 the share of employed women in the USSR stood at 96.8 per cent compared to 71.1 per cent in Northern Europe, 55.6 in Western Europe and 37.1 in Southern Europe. ${ }^{70}$ It is interesting that even in the 1890s, women composed nearly one quarter of all those employed in Russia's industrial production. ${ }^{71}$ In 1910 s this figure came close to 40 per cent and it stood at nearly 70 per cent in the textile industry. ${ }^{72}$ Liberal feminists therefore are proud that contemporary Russia also sustains a high level of women's employment. Maltseva and Roshchin show that in 2006, 60.8 per cent of economically active women (those aged between 15 and 72) participated in the country's labour market, while this figure stood at 70.4 per cent among men. ${ }^{73}$ More importantly, within the 25-54 age group, this figure was at 85.82 per cent, comparing favourably again to OECD countries, in which employment for the same category of women stood at 69 per cent for the same year.

With regards to women employed in political institutions, these researchers also praise recent developments, in which women began to occupy important positions within Russia's political structures. ${ }^{74}$ Among the most often

\footnotetext{
${ }^{69}$ Gunderson, M. (1989) 'Male-Female Wage Differentials and Policy Responses', Journal of Economic Literature, Vol. 27, pp. 46-72, at p. 47.

70 Barr, N. (1997) Rynok Truda i Sotsialnaia Politika v Tsentralnoi i Vostochnoi Evrope. Perekhodnyi Period i Dalneishee Razvitie (Moscow: IKTs DIS), p. 174; Maltseva and Roshchin 2006, p. 16.

71 Stites 1978.

72 Chirikova 1998, p. 5.

73 Maltseva and Roshchin, 'Gendernaia Segregatsia' 2006, p. 15.

74 Seltser 2003; Pozniakov (2006) 'Gendernye Osobennosti Sotsialno-Psikhologicheskikh Kharaketeriskik Rossiiskikh Predprinimatelei' (Moscow: Institut Psikhologii RAN); Chirikova
} 
mentioned women are the Head of the Central Bank Elvira Nabiullina and her deputy Ksenia Iudaeva, the Head of the Federation Council and former governor of St Petersburg Valentina Matvienko, Russia's Minister of Health Veronika Skvortsova, Minister of Social Development Olga Golodets, presidential advisor and the head of the Accounts Chamber Tatiana Golikova and her deputy Vera Chistova, former Minister of Agriculture Elena Skrynnik, the head of the State Duma anti-corruption committee Irina Iarovaia, press secretary of the Ministry of Foreign Affairs Maria Zakharova, press secretary of Russia's Prime Minister Dmitry Medvedev Natalia Timakova, former head of the Union of Right Forces Party Irina Khakamada and many others. Aivazova argues that during the postSoviet decades the proportion of women in federal legislative institutions has grown considerably. ${ }^{75}$ The 2007 parliamentary elections ensured 63 mandates for women, which comprised 14 per cent of all parliamentary seats. This compares favourably to the previous rounds of general elections, in which only 34 and 44 women entered the 2000 and 2003 convocations of the federal parliament respectively.

Researchers of the egalitarian trend also observe that women penetrate municipal and regional administrations, city councils, city mayoral and vicemayoral positions, as well as village and small town councils. Chirikova and Lapina argue that in regional executive positions, the share of women is $1.5-2$ times higher than that at the federal level. ${ }^{76}$ Researchers explain the active arrival of women in municipal and village levels of power by the relatively

2001; Chirikova and Lapina 2009, p. 10-2; Aivazova 2008, p. 86; Khakamada, I. (2002) Osobennosti Natsionalnogo Politika (Moscow: Olma Press).

${ }^{75}$ Aivazova, 2008, pp. 86-9.

${ }^{76}$ Chirikova and Lapina 2011 'Zhenshchina na Vysshikh Etazhakh'. 
unattractive and underfinanced position of these institutions. In addition, they claim that at such levels people have the chance of a genuine/personal choice between candidates and women often demonstrate activity and a positive attitude.

Feminists of difference mostly point at the problem of a wage gap between men and women. In particular, they claim that, according to the Russian Statistics Service, Russian women earn 30-35 per cent less than men. ${ }^{77}$ The situation seems much worse than in most West European countries, where women earn on average 10-15 per cent less than men for performing similar jobs. Briefly covering higher paid segments of the population, feminists of difference claim that Russian women tend to play down their abilities at the recruitment stage. This results in women achieving 20-30 per cent less pay than their equal male counterparts earn for performing identical jobs. ${ }^{78}$

Recruitment agencies point at the problem of 'internalised misogyny'. This means that women voluntarily embrace their socially constructed inferiority in the male-dominated professional fields and act in accordance with those labels. Women habitually refuse to demand wages suggested to them by HR specialists feeling that they could not earn 'that much'. This is particularly true in the Russian IT industry, which is dominated by men at both educational and professional stages. Some HR specialists claim that this state of affairs occurs because women are being educated in a patriarchal framework and are told at an early stage that they are a-priory inferior to men in the fields of mathematics,

\footnotetext{
77 Khasbulatova 2001 'Rossiiskaia Gosudarstvennaia Politika', p. 191.

78 '8 Marta - prazdnik dlia kogo?’.
} 
logic, IT, and natural sciences. ${ }^{79}$ The capitalist market, on the other hand, demands employers to minimise expenses. Hence, both employers benefit from women's inferiority complex by willingly employing cheaper workforce of equal or superior quality.

This situation is exacerbated by the fact that in nearly 30 per cent of Russian families women assume leading positions, acting as the main breadwinner. Marina Karavaeva, a member of the gender relations faction of the liberal Yabloko party, insists that there are six million Russian families in which women raise children alone compared to only 635,000 families, in which men act as single fathers. ${ }^{80}$ In 80 per cent of cases, fathers avoid paying child maintenance, while state support agencies that are tasked with the child maintenance enforcement duties do not perform their job properly. More importantly, official statistics are unavailable to analyse this problem. The aforementioned figures are sourced from independent activists groups, which deal with the issue directly. In this light, Russian feminists of difference propose to establish a state child maintenance fund, which could assist women whose expartners avoid contributions. The state, in their mind, should open a specific debt account against such fathers and consider unpaid maintenance fees as state debts owed by these men.

Second, let me discuss the attitude of the two strands of feminism to the professional gender segregation problem. Such segregation takes place when we see a disproportionately high concentration of one or another gender in a

\footnotetext{
79 'Pochemy Zhenshchiny Dolzhny Zarabatyvat Bolshe, Chem Muzhchiny: Kak Prevratit Nizkuyu Samootsenku v Vysokuyu Zarplatu', gazeta.ru, 6 March 2015, available at http://www.gazeta.ru/lifestyle/style/2014/10/a 6250505.shtml, last accessed 15 March 2015.

80 '8 Marta - prazdnik dlia kogo?', Radio Liberty, available at http://www.svoboda.org/audio/26886064.html, 8 March 2015, last accessed 1 May 2015.
} 
particular professional group or in particular hierarchical positions within one professional group. Researchers distinguish between 'vertical' and 'horizontal' types of this phenomenon. 'Vertical segregation' assumes unequal redistribution of men and women in hierarchical positions within one firm. 'Horizontal segregation', on the other hand, assumes industry segregation between men and women in various professional spectra. Both types of segregation are interconnected. Horizontal segregation also has a vertical dimension due to the perceived status difference between various professions. ${ }^{81}$

Liberal feminists usually argue that equating professional gender segregation with purposeful discrimination of women is inadequate. They claim that professional gender segregation is a result of a multitude of factors of social, economic, political, professional, aspirational and vocational natures, as well as mere individual preferences. ${ }^{82}$ They argue that gender discrimination represents the result of a general lack of social mobility existing within Russian society and the idiosyncratic political system that has been established in Russia during the post-Soviet period. Resolving these problems through consistent policy-making in a gender-blind fashion would help to alleviate the problem of gender misbalance in work places. ${ }^{83}$ This approach is reminiscent of the Engelsian (1884) idea of mending the capitalist society in general in order to resolve the 'women's question' in particular. ${ }^{84}$

\footnotetext{
${ }^{81}$ Maltseva and Roshchin 2006, 'Gendernaia Segregatsiia', p. 11

82 Ibid. p. 10.

83 Mezentseva 2000 'Gendernaia Ekonomika'.

${ }^{84}$ Engles, F. (1884/1972) The Origins of the Family, Private Property and the State (London: Penguin Classics).
} 
Focusing on vocational explanations, these feminists argue that the concentration of men in various professional positions to some extent represents a choice by women who prefer to assume domestic responsibilities for historic, as well as contemporary economic, reasons. Roshchin, following the analysis of Russian women's preferences during the 1990s, observes that almost 20 per cent of respondents were willing to leave the labour market in order to focus on household duties, if they had an alternative source of income, including that provided by their husbands. ${ }^{85}$ Hence, these researchers claim that the high proportion of women's employment in Russia represents partly, the result of the inability of men to support their families. These findings correspond to the more recent research of Russia's middle class women conducted by Temkina. This, as we mentioned above, claims that most such women find private household as a new sphere of self-realisation. ${ }^{86}$

Speaking of the professional segregation of women in politics, feminists of equality complain about the general lack of transparency within Russia's political institutions. These authors claim that the construction of 'power vertical' narrowed the space for public politics in Russia in general and affected the cause of women's liberation in particular. ${ }^{87}$ The process of women's recruitment to power remains informal and lacks any meaningful structure. Arrival of women (and, as a matter of fact, men) in politics mostly depends on the arbitrary choice of the most senior persons in executive positions or financial status of

\footnotetext{
85 Roshchin, S. (1996) Zaniatost Zhenshchin $v$ Perekhodnoi Ekonomike Rossii (Moscow: Ekonomicheskii Fakultet MGU TEIS).

86 Temkina, A., Zdravomyslova, E., Rotrikh, A. (2009) 'Sozdanie Privatnosti'.

${ }^{87}$ Kryshtanovskaya, O. (2005) Anatomiia Rossiiskoi Elity (Moscow: Zakharov); Maltseva and Roshchin 2006, p. 95; Chirikova and Lapina 2009, p. 12-3; Khakamada 2002, p. 122.
} 
candidates. ${ }^{88}$ Hence, the existing 'caste structure', in which most decisions are taken arbitrarily, serves as a barrier for talented and educated women on their path to power. ${ }^{89}$

Chirikova and Lapina further claim that the newly emerged conservative trend in Russia, in which state-patriotic ideas have gained significance, further impeded women's chances to enter political institutions. ${ }^{90}$ This is because the style and the language of politics have become masculine, inadvertently gearing towards selecting male candidates for important political positions. Opinion polls show that both men and women have internalised this misogynist position. 60 per cent of the Institute of Sociology survey/poll respondents claimed that a woman president would have a negative impact on Russia's socio-political evolution. ${ }^{91}$ Feminists of equality arrive at the conclusion that the general liberalisation of Russia's society and a change of a dominant ideological paradigm could result in the achievement of a fairer gender balance in politics. It now becomes apparent that such an egalitarian approach looks to resolve women's problems through enhancing general institutional transparency and struggling for human rights in the 'colour-blind' fashion reminiscent of liberal feminism in the West.

To expand this position, feminists of difference are inclined to think that the 'vertical' and 'horizontal' professional segregations happen because Russia's contemporary society is constructed on the basis of a male image as a social

\footnotetext{
${ }^{88}$ Chirikova and Lapina (2011) 'Zhenshchina na Vysshikh Etazhakh', p. 13.

89 Ibid., p. 12; Kanakianova, R. (2006) 'Sovremennye Tendentsii Preodoleniia Gendernoi Asimmetrii v Gosudarstvennom Upravlenii', Vlast, No. 12.

${ }^{90}$ Chirikova and Lapina (2011) 'Zhenshchina na Vysshikh Etazhakh', p. 13.

${ }^{91}$ Ibid., p. 13; ISPI RAN (2002) Zhenshchina Novoi Rossii: Kakaia Ona? Kak Zhivet? K Chemu Stremitsia? (Moscow: ISPI RAN Publications), p. 14.
} 
norm. Natalia Bitten, a member of the Za Feminizm social movement, argues that women are punished for the fact that they perform childbearing functions. Bitten claims that 'women are less likely to be promoted because of their perceived hormonal 'instability', because they could consider leaving their career to focus solely on child-rearing engagements, because they might already be splitting their attention between their job and child care, because, in case of child's illness, women, and not men, would have to take sick leave. Men, on the other hand, are considered more stable, more mature, and more advantageous job applicants if they have family and children'. ${ }^{92}$

Marina Baskakova, researching a number of Russia's regions, further continues that motherhood in contemporary Russia often involves the loss of a woman's professional status and an impact on career progression. ${ }^{93}$ Women with children could search for jobs for years, while employers habitually violate the Constitution by refusing them placements. The state is being deliberately silent on these matters, usually based on ideological grounds of non-interference in traditional family matters. This pushes women further into a socially excluded group and results in the loss of self-confidence. In this light, Vera Akulova claims that 70 per cent of all Russia's destitute are women. 60 per cent of all Russia's illiterate population are also women. The elite echelon segment is only 14 per cent women. This situation, she argues, is a little better than in the United States

\footnotetext{
92 '8 Marta - prazdnik dlia kogo?', Radio Liberty, available at http://www.svoboda.org/audio/26886064.html, 8 March 2015, last accessed 1 May 2015.

93 Baskakova, M. (1995) 'Zamuzhniaia Zhenshchina: Semia ili Rabota?' Semia v Rossii, No. 3-4, pp. 101-8.
} 
and North America but much worse than in most European, and in particular, Scandinavian countries. ${ }^{94}$

In this light, many feminists of difference suggest that the state must introduce equal statutory benefits for taking sick leave for child care, equal length and pay for maternity and paternity leave. ${ }^{95}$ This would create the situation, in which employers would feel no difference between male and female employees, as both parties could equally be engaged in the child rearing process. This could give women more chances for fairer treatment in the job market and break away from social exclusion and poverty. Akulova further points out that Russian women work in the lowest paid job sectors, such as pre-school education, medicine, caring and nursing. Russia's increased military spending and ensuing government cuts within the social care segments exacerbate this situation. This has led to a significant reduction in statutory pay and benefits within professions mostly populated by women - a situation that will plunge women further into poverty and dependence on their male partners.

\section{Conceptions of Power and Citizenship}

Researching different models of power practiced by Russian women within political and business institutions, proponents of equality feminism adopt a rather nuanced approach. In the sphere of politics and business administration, researchers of egalitarian trends often claim that the style of management in Russian power institutions, as well as in medium-sized and small business companies, is androgynous. They argue that there is no fundamental difference

\footnotetext{
94 'Feminizm v Rossii', Zhivoi Razgovor, Setevizor, 30 March 2013, available at https://www.youtube.com/watch?v=aOYNHmX9bVk, last accessed 7 June 2016.

95 Bitten 2013 'Biet - Znachit Luibit'; Neifeld, G. (1998) 'Zhenshiny v Rossii v Kavychkakh i Bez', Itogi, No. 83.
} 
between male and female forms of management. At the same time, they note that, despite no significant gender difference in the style of management, women can be more flexible and inventive by deploying both female and male styles of directorship. In sensitive situations women could be more compassionate and consensus seeking. Yet, if the situation demands, they can be harsh, firm, aggressive and uncompromising to match all the socially perceived masculine traits. ${ }^{96}$ Hence, the description of Russia's women in power emerges as rather nuanced. On the one hand, liberal authors tend to notice that women adopt the Arendtian consensual model of power, in which a leader relies on the group as a source of his/her influence. On the other hand, these writers claim that such a behavioural model does not represent a hard and fast rule. Hence, despite admitting some behavioural differences between men and women in business and power, researchers refrain from drawing fixed division lines. ${ }^{97}$

In the first case, Irina Khakamada, describing women's behaviour in politics, claims that their role is to mitigate conflicts, placate opponents and seek consensus. Khakamada further argues that women can tame their ambitions and adopt a consensual style of governance. ${ }^{98}$ Chirikova, following her rigorous research of day-to-day situations, insists that most women prefer to rely on the so-called 'expert' or 'charismatic' models of power, which is reminiscent of the Arendtian idea of consensual power. At the same time, Chirikova's focus group respondents claim that they combine consensual power practices with

\footnotetext{
${ }^{96}$ Chirikova 2011, 'Zhenshchina-Rukovoditel', pp. 146-7.

${ }^{97}$ Chirikova 2011; Pozniakov, V. and Titova, O. (2005) 'Konkurentnye i Partnerskie Otnosheniia Rossiiskikh Predprinimatelei: Regionalnye i Gendernye Osobennosti' in Zhuravlev, A. (ed.) Problemy Ekonomicheskoi Psikhologii, Vol. 2, (Moscow: Institut Psikhologii RAN), pp. 181-204; Pozniakov, V. and Titova, O. (2002) 'Psikhologicheskie Otnosheniia Rossiiskikh Predprinimatelei: Gendernye Osobennosti', Vestnik RGNF, No. 3, pp. 162-173.
}

98 'Portret Politika', 2002, p. 138 and p. 154. 
conflictual methods of influence when necessary. In consensual situations, such women deployed their expert knowledge to motivate subordinates into submission via respect and recognition. At the same time, when the situation called, these same women deployed the conflictual style, acting in an uncompromising fashion, drafting company rules, and compelling employees to submission. ${ }^{99}$

Pozniakov and Titova from the Russian Institute of Sociology go a step further. They claim that women in top power positions adopt masculine models of behaviour and achieve similar results as men relying on the conflictual model of power alone. ${ }^{100}$ In general, these authors claim marginal behavioural gender differences in important positions of power. Statistical analysis within chosen focus groups demonstrates that the amount of women and men choosing competition, co-operation, compromise, and avoidance as a means of resolving conflicts respectively does not differ significantly. ${ }^{101}$ The authors further assessed business focus groups for various models of power behaviour from the point of view of risk taking strategies, attitude to competition, and selfconfidence. Drawing on statistical analysis, Pozniakov and Titova claim that perceived behavioural stereotypes, in which women are less prone to risk-taking or seek to avoid conflict and competition, exist but do not have overwhelming explanatory power. For example, only 13.6 per cent of women respondents did not like competition against 10.7 per cent of male respondents. Yet, 15.7 per cent of men strongly prefer a competitive style of management against just 9 per cent

\footnotetext{
${ }^{99}$ Chirikova 2011, 'Zhenshchina-Rukovoditel'.

100 Pozniakov, V. and Titova, O. (2005) 'Konkurentnye i Partnerskie Otnosheniia'; Pozniakov, V. and Titova, 0. (2002) 'Psikhologicheskie Otnosheniia'.

101 Pozniakov (2006) 'Gendernye Osobennosti'; Chirikova 1998, 'Zhenshchina vo Glave'.
} 
of women exhibiting a similar preference. Nevertheless, women respondents assessed their success in business to 5.14 points out of ten on average, while men had a 4.68 points result. Both groups assessed the results of their activity at 4.5 and 4.24 points and their abilities at 5.32 and 5.0 points respectively. These findings testify to a relatively similar level of self-confidence among men and women. ${ }^{102}$ These researchers do not lament the situation that women 'voluntarily accepted' male forms of behaviour, as would their counterparts from the feminism of difference camp do. Rather, they conclude that contemporary Russia formed a relatively homogenous group of business entrepreneurs and industrial leaders that has similar psychological features and only marginal gender differences within the group.

Feminism of difference remains silent on the issues of power models. It does however ponder the ideas of citizenship in Russia. These feminists usually consider both liberal or rights-based and republican paradigms, making their approach to the problem nuanced and multi-faceted. Let me consider their view on both models of citizenship. In the liberal sphere, feminists of difference claim that their movement contributes to the expansion of political and social rights in Russia. Elena Petrovskaya, a senior research associated at the Institute of Philosophy RAN, claims that, apart from the rights of women, feminist movements in Russia also fight for a more active implementation of the liberal rights-based idea of citizenship. Women's movements, she argues, could help expand the social rights of pensioners or contribute to the drafting of clearer legal codes for the humane treatment of animals. 'Feminism', Petrovskaya claims,

102 Pozniakov (2006) 'Gendernye Osobennosti'; Pozniakov and Titova (2005) 'Konkurentnye i Partnerskie Otnosheniia'. 
'becomes a synonym for tolerance and a particular ethical standpoint. It stands against general patterns of repression, social exclusion, and inequality. It is an emancipatory position that manifests itself at different levels of socio-political life'. ${ }^{103}$ In this light, Russian feminists of difference advocate greater rights for various segments of society. Women's rights are as important as any other aspect of human rights and they must be included as a separate item on the entire range of rights that the state and society considers in its policy-making. ${ }^{104}$

Within the republican model of citizenship, feminists of difference claim that the public good is best served by protecting the rights of women. They insist that women must obtain greater social rights. Such rights must consider women's problems relating to childbirth and motherhood. Only through creating an environment, in which women would feel greater protection for themselves and their children, the state could have fully participating and committed citizens. ${ }^{105}$ It could then succeed in securing a harmonious and just society - an achievement that represents the most important aspect of the public good.106

Regardless of the emphasis that such feminists make in their theorisations on citizenship, they all agree that the model citizen in Russia is built around the norm, ideal, and lifestyle of men. ${ }^{107}$ In this light, these feminists argue that the Russian government must introduce the position of a human rights ombudsman who would defend specifically the rights of women. As Bitten argues, any gender-blind ombudsman position in Russia would mean a

\footnotetext{
103 'Vozmozhen li Feminizm v Rossii?', Radio Free Europe, Radio Liberty, 16 September 2011, available at https://www.youtube.com/watch?v=zRlBWeCvJow, last accessed 1 May 2015.

104 '8 Marta - prazdnik dlia kogo?'; Gessen, M. (1998)‘Litsa' .

105 Ibid.

106 Akulova (2013) 'Feminizm'.

${ }^{107}$ Akulova 2013; Bitten (2015) '8 Marta’
} 
systematic defence of the rights of men. ${ }^{108}$ Hence, women's rights must be defended separately as they are permanently discriminated against by the very fact of a male-dominated society.

\section{CONCLUSION}

This paper examined theoretical and empirical debates that take place in contemporary Russia between the two complimentary strands of feminism: feminism of equality and feminism of difference. The paper reiterated the argument of some Russian feminists that the immediate post-Soviet generation of women often espouses feminism of equality due to the pre-established patterns of gender socialization that existed in the Soviet Union. At the same time, the development of a capitalist mode of politics and economics also led to the emergence of a feminism of difference that raises qualitatively different themes and problems.

This article demonstrated that feminism in its complex entirety is highly relevant to Russia's pressing economic and political challenges and represents an important part of the country's ideological landscape. Feminism of difference is concerned with issues and problems experienced by lower income women that face socio-economic exclusion at various levels. These thinkers call to recast the entire spectrum of social relationships in order to account for women's unique problems and perceptions. They focus on issues of socio-economic exclusion, domestic violence, and exploitation. Feminists of equality are mainly concerned with economic and labour relations. They fend for the rights and

\footnotetext{
108 Ibid.
} 
problems of successful women. They press for the equal share of women within Russia's institutions of power, viewing power in mostly masculine terms.

The state, in its current conservative aspirations, pays attention to this conceptual differentiation within Russian feminism, even though it could be considered as cursory at times. At some ideological junctions, the positions of selective strands of feminist reasoning crisscross with the goals of the state. The state tends to co-opt and deploy those positions that could present a situational ally in the purpose of resurrecting Russia's nativist political path and its marriage to the post-Soviet capitalist modernity. At most points, however, both strands of feminism represent a critical intellectual force that censures the policies of the Russian state in various policy segments. Hence, both trends of feminism could be considered as complimentary in their contributions to forming a necessary social fabric that could accelerate the dialogue between the state and society from the critical, and in this case, feminist point of view. 